\title{
The intricate question of European democracy: national parliamentary debates on the European Elections Act of 1976
}

\author{
Hilde REIDING, Joachim WINTZER, Thorsten BORRING OLESEN, Marloes \\ BEERS, Valentine LOMELLINI
}

On 20 September 1976, the member states of the European Community signed the 'Act concerning the Election of the Representatives of the Assembly by Direct Universal Elections', which was to introduce direct elections for the European Parliament in the member states. National parliamentary debates about the principle as well as the implementation of these elections were held in every member state. On the basis of these debates, this article investigates the ideas about European democracy that existed among members of national parliaments. It demonstrates that there were fundamentally different philosophies about the role of the European Parliament and its relation to national parliament and various thoughts about the nature of European representation and the link to the voters. Finally, the article explores to what extent the national parliamentary debates can truly be seen as parts of a European debate. ${ }^{1}$

\section{A long road to European elections}

Since the 1990s, it has become commonplace to associate European integration with a so-called 'democratic deficit'. ${ }^{2}$ Although, for various reasons, the question of how to make the European institutions more accountable to the people has indeed become more urgent during the last two decades, the idea that no serious thought had ever been given to that matter in previous years is misleading. From the start of the integration process, awareness existed that accountability mechanisms would be needed. ${ }^{3}$ For a long time, the focal point for discussions about European democracy was

1. This article is based on case studies by Hilde Reiding (the Netherlands, the United Kingdom, Ireland), Joachim Wintzer (Federal Republic of Germany, Belgium), Thorsten Borring Olesen (Denmark), Marloes Beers (France) and Valentine Lomellini (Italy). The text of the article was written by Hilde Reiding and commented upon by the other authors.

2. A British Labour MP and political analyst, David Marquand, first coined this term in the 1970s. See: P. MAGNETTE, Democratic deficit, in: Y. DÉLOYE, M. BRUTER (eds), Encyclopaedia of European elections, Palgrave Macmillan, Basingstoke, 2007, pp.69-71, here p.69. For its increased use in academic and newspaper articles, see: B. RITTBERGER, Building Europe's parliament. Democratic representation beyond the nation-state, Oxford University Press, Oxford, 2005, pp.28-29.

3. See, for instance: B. RITTBERGER, op.cit., pp.78-81 and 98-104; C. HOETINK, K. VAN LEEUWEN, Dilemmas of democracy. Early postwar debates on European integration in the Netherlands, in: J. GIJSENBERGH, S. HOLLANDER, T. HOUWEN, W. DE JONG (eds), Creative crises of democracy, Peter Lang, Brussels, 2012, pp.183-212. Under the working title Democracy in Words and Deeds in the European Communities, a more extensive study on democratic ideals and practices in the early years of European integration (1950-1967) is currently carried out by a Dutch historian, Koen van Zon. Publication is due for late 2018. 
the European Parliamentary Assembly, or the European Parliament, as it started to call itself from $1962 .{ }^{4}$

The fact that the Assembly gave itself this new name already demonstrates that it had the aspiration of distinguishing itself from conferences and assemblies of national parliamentarians of intergovernmental organizations, such as the Council of Europe or NATO, and wanted to gain a position that resembled that of a national parliament. ${ }^{5}$ This would require additional powers as well as a direct mandate from the people whom the members of the European Parliament (MEPs) represented. The European treaties gave reason to expect that, one day, at least the ambition to be directly elected could come true. The Treaty of Paris that established the European Coal and Steel Community (ECSC) in 1952 had left it to the individual member states to decide whether they preferred to send representatives from their national parliament to the ECSC's Common Assembly or to have them directly elected by the people. ${ }^{6}$ In practice, all member states decided to designate national parliamentarians, among others to guarantee that Communists would be excluded. ${ }^{7}$ Yet, for those who wanted the Assembly to become more of a parliament, the fact that elections were formally recognized as an alternative could be a source of hope.

In the Rome Treaties of 1957, a different point of departure was chosen. It was stipulated that, for the time being, member states would designate representatives from their national parliaments. However, on the initiative of Italy, an article was included in the EEC Treaty that read:

'the Assembly shall draw up proposals for elections by direct universal suffrage in accordance with a uniform procedure in all member states. The Council shall, acting unanimously, lay down the appropriate procedures which it shall recommend to the member states for adoption in accordance with their respective constitutional requirements' ${ }^{8}$

The European Parliament did not hesitate to take up its mandate: a committee chaired by Fernand Dehousse prepared a report and a draft convention, which was sent to the Council of Ministers for approval in 1960. Five member states - the Federal Republic of Germany, Italy, the Netherlands, Belgium and Luxembourg - were willing to con-

4. The discussion about its denomination started directly after the Treaties of Rome had entered into force. Both names were used until the Single European Act (1986) decided in favour of 'European Parliament'. For practical reasons, the term 'European Parliament' will be used in this text, unless there is a specific reason not to do so (e.g. quotations in which the term Assembly is used or references to the period before 1958).

5. L. VAN MIDDELAAR, The passage to Europe. How a continent became a Union, Yale University Press, New Haven/Londen, 2014 (paperback), p.281.

6. See article 21 of the Treaty establishing the European Coal and Steel Community: 'The Assembly shall be composed of delegates whom the parliaments of each of the member states shall be called upon to designate once a year from among their own membership, or who shall be elected by direct universal suffrage, according to the procedure determined by each respective High Contracting Party'.

7. U. TULLI, Which democracy for the European Economic Community? Fernand Dehousse versus Charles de Gaulle, in: Parliaments, Estates and Representation, 3(2017), pp.301-317, here p.304.

8. F. PIODI, Towards Direct Elections to the European Parliament. Paper Written to Mark the 30 $0^{\text {th }}$ Anniversary of Direct Elections (June 1979)', in: CARDOC Journals, 4(March 2009), p.15. (See: http://www.europarl.europa.eu/pdf/cardoc/Direct_elections.pdf, accessed: 23.02.2018. 
sider the proposal, but France pertinently refused to accept direct European elections. As a consequence, a long period of inaction followed.

At the Hague Summit of 1969, the Heads of State or Government announced that the Council would give the matter further attention, but it would take until the 1970s before any real momentum could be created. After a change of government in France, the Heads of State or Government expressed their will to reach agreement on the matter at the Paris Summit of December 1974, and announced that elections should take place no later than 1978. In the European Parliament, there were new developments too. In 1973, a rapporteur (Schelto Patijn) was appointed to write a new and up-to-date draft, taking into account the accession of three new member states: the United Kingdom, Denmark and Ireland. Because it was apparent that one common electoral system would not be feasible, the treaty left it to the member states to design their own electoral systems. A uniform system would be drawn up once the political conditions were there. ${ }^{9}$

The European Parliament's draft was the basis for the negotiations between the member states that took place from the second half of 1975 to July 1976. One of the most controversial issues was the question of the European Parliament's size and the distribution of the seats. Other problems were the question on which day of the week the elections should take place (each country had its own conventions) and the question whether a dual European and national parliamentary mandate should be compulsory or optional. Final agreement was reached on 12 July 1976, and on 20 September of that same year, the 'Act concerning the Election of the Representatives of the Assembly by Direct Universal Elections' was signed. ${ }^{10}$

With the agreement of the governments a major hurdle was taken. However, before the elections could take place, the approval of all nine member states' national parliaments was required. The parliaments had to give their consent to the principle of the elections as well as to the specific election rules their governments designed. Due to delays in these legislative procedures, the target date of May/June 1978 could not be met and the member states decided to postpone the elections with one year. They were to take place between 7 and 10 June $1979 .{ }^{11}$ Considering the fact that these were the first multinational popular elections ever, it was an historical event: no less

9. Up to now, it has appeared impossible to realize a uniform system though. For an overview of attempts made, see: D. PASQUINUCCI, Towards an historical approach to the European elections, in: Working Paper AUSE, 03.2008, pp.14-34. (See: http://www.ause.eu/public/medias/ 2008_3_2008_D_PASQUINUCCI.pdf, accessed: 23.02.2018).

10. This account of events leading towards the adoption of the Act is based on: V. HERMAN, Direct elections: historical background, in: V. HERMAN, M. HAGGER (eds), The legislation of direct elections to the European Parliament, Gower Publishing, Farnborough Hants, 1980, pp.14-29; G. BRUNN, Das Europäische Parlament auf dem Weg zur ersten Direktwahl 1979, in: F. KNIPPING, M. SCHÖNWALD (eds), Aufbruch zum Europa der zweiten Generation. Die europäische Einigung 1969-1984, Wissenschaftlicher Verlag Trier, Trier, 2004, pp.47-72; F. PIODI, op.cit., pp.15-37.

11. F. PIODI, op.cit., p.38. 
than $184,113,418$ voters from nine European countries were allowed to bring out their votes, which 62,3 percent of them actually did. ${ }^{12}$

\section{Two years of national parliamentary debate}

In light of the distinctive nature of the event, it is remarkable to note that the direct election reform has attracted relatively little academic attention, especially among historians. ${ }^{13}$ The most important studies on the 1979 elections have been written by political scientists and appeared in the first half of the 1980s. Among them were a series of articles concerning the individual countries' preparations for the elections and three all-member state studies: an edited volume that dealt with election campaigns and election outcomes, a study that investigated electoral communication and a book that aimed to systematically compare the member states' legislative procedures and to draw lessons for a future uniform electoral system. ${ }^{14}$ Although the latter study pays attention to the parliamentary ratification and implementation debates, generally speaking, it can be maintained that academics concerning themselves with the phenomenon of European elections have tended to concentrate on operational aspects, campaigns and results. Thus far, the underlying ideas and expectations about direct European elections have not received much attention.

Considering that the European Parliament and national parliaments were (or were at least supposed to be) constituent parts of one European polity, knowing about these ideas and presumptions is highly relevant, especially if one realizes that perceptions can be an influential factor in shaping a parliament's policy choices and its attitude towards other actors and institutions. ${ }^{15}$ Hence, to gain more insight into the question of the possibilities and limitations of European democracy in past and present, it is necessary to become aware of the views that were present in the member states' national parliaments.

This article deals with national parliamentary images of European democracy in the second half of the 1970s. In the period between the decision at the EC Paris summit of 1974 to aim for the introduction of direct elections in 1978 and the first direct

12. K. REIF, Ten second-order national elections, in: K. REIF (ed.), Ten European elections. Campaigns and results of the 1978/81 first direct elections to the European Parliament, Gower Publishing Company, Brookfield, 1985, pp.1-36, here p.1.

13. Two exceptions are: D. PASQUINUCCI, Uniti dal voto. Storia delle elezioni europee 1948-2009, Franco Angeli, Milan, 2013; U. TULLI, Un parlamento per l'Europa. Il Parlamnto Europeo e la battaglia per la sua elezione (1948-1979), Le Monnier, Florence, 2018.

14. K. REIF (ed.), op.cit.; J.G. BLUMLER (ed.), Communicating to voters. Television in the first European parliamentary elections, Sage Publications, London, 1983; V. HERMAN, M. HAGGER (eds), op.cit. A series of articles was published in volumes 15 and 16 of the Common Market Law Review.

15. For an example, see: H. REIDING, W. VAN MEURS, Z. HULSENBOOM, Die europäische Subsidiaritätsprüfung auf dem Prüfstand. Erwartungen und erste Erfahrungen aus dem deutschen und dem niederländischen Parlament, in: Zeitschrift für Parlamentsfragen, 1(2016), pp.85-101. 
elections held in 1979, the question of European elections was intensively debated in all member states' national parliaments, thus providing an excellent opportunity to gain insight not only into the blunt question of whether or not national parliamentarians supported these elections, but also, more importantly, into quite fundamental and inextricably related issues regarding, for instance, the location of European democracy and the link with the people.

In the ratification and implementation debates, national parliamentarians gave expression to their ideas about the nature and potential power of the European Parliament and to their expectations about the role and responsibilities of the newly elected members of this parliament, to which they would have to relate their own position as well. Should European democracy primarily be located at the European level, or at the national level? And what kind of relationship should there be between a directly elected European Parliament and the national parliaments?

The debates also shed light on national parliamentarians' beliefs about whether and how these elections could bring the people and 'Europe' together. Would the elections be meaningful for ordinary people and increase their interest in European affairs? Or were voters just expected to legitimize the European Parliament and European policies? And who were the voters anyway? Did national politicians regard voters primarily as the national representatives' constituencies, or as European voters or even citizens belonging to a European public sphere in the making?

\section{The course of events in the nine parliaments}

In the majority of member states, national parliaments had to discuss at least two, or sometimes even three separate bills: one to ratify the European Elections Act, the other one, or ones, to arrange for its actual implementation. In Ireland, the United Kingdom and Denmark, there was no ratification bill; here, the parliamentary tradition prescribed that approval for treaty ratification followed from the adoption of implementation law.

Closely related to power relations between political groups, the electoral procedures' design was a delicate matter in almost every member state. There was an ECwide tendency of smaller parties criticizing the proposals, because they generally worked out unfavourably for them. ${ }^{16}$ To mention an example, the disadvantageous position of numerically minor parties was one of the most controversial issues in Dutch parliament. Since there were fewer seats to be distributed among the parties, the election threshold was much higher than it was for national elections in the Netherlands. After proposals to improve their chances had been rejected, all small parties voted against the implementation bill to give expression to their dissatisfac-

16. M. HAGGER, Towards a comparison of nine legislative processes, in: V. HERMAN, M. HAGGER (eds), op.cit., pp.260 and 278. 
tion. ${ }^{17}$ Due to their minority position, this remained without consequences. Yet, in a number of other member states, issues occurred that seriously delayed the adoption of the election bills. Italy was a clear case in point: here, the government was confronted with a situation in which it had to meet the demands of a large but very heterogeneous parliamentary majority and it was difficult to formulate an acceptable compromise. ${ }^{18}$

Three other countries where the adoption of the implementation law proved particularly problematic were the Federal Republic of Germany, Belgium and the United Kingdom. In the Federal Republic of Germany, the main point of contention concerned the question whether a federal list system or a system based on the component states (Länder) was to be preferred. The eventual compromise that was agreed on was that lists could be established for either a single Land or several Länder together. Hence, it was up to the parties to decide whether they wanted to have one combined federal list or separate Land lists. ${ }^{19}$

In Belgium, legislation was complicated mainly because of the country's internal struggle to regulate political relations between its linguistic communities. The bill's design as well as its parliamentary treatment were inevitably influenced by the political tug-of-war around this matter. The basic idea was to divide the country in three areas: Flanders, Wallonie and Brussels. Voters of the latter (bi-lingual) area could choose whether they wanted to vote for the Flemish or the French-speaking list. For the German-speaking minority in the Eastern part of the country, no special arrangements were made. In parliament, lengthy debates took place in which representatives of each language group tried to amend the law to their own advantage, but eventually it passed virtually unchanged. ${ }^{20}$

In the United Kingdom, problems about the electoral arrangements were related to the Labour government's dependence on a non-government coalition party. In 1976, Labour had lost its majority in parliament and to survive this situation, it had negotiated a pact with the Liberal Party. This party was strongly committed to electoral reform and wished to see the British first-past-the-post system replaced by proportional representation. This kind of reform was disliked by both major parties in parliament, but since the government had agreed to take the Liberal preferences into account, two options were included in the bill: the traditional plurality system and a

17. R. VAN SCHENDELEN, The Netherlands: last but not least, in: V. HERMAN, M. HAGGER (eds), op.cit., pp.183-203, here p.198.

18. M. COTTA, Italy: how a quick start became a late arrival, in: V. HERMAN, M. HAGGER (eds), op.cit., pp.144-167, here pp.155-164.

19. J. LODGE, Germany: Modell Deutschland, in: V. HERMAN, M. HAGGER (eds), op.cit., pp.77-98, here pp.87-95; M. BANGEMANN, Preparations for direct elections in the Federal Republic of Germany, in: Common Market Law Review, part I, 3(1978), pp.321-335, here pp.323-325 and part II, 2(1979), pp.241-242.

20. D. HEARL, Belgium: two into three will go, in: V. HERMAN, M. HAGGER (eds), op.cit, pp.30-53, here pp.32-45; L. NEELS, Preparations for direct elections in Belgium, in: Common Market Law Review, part I, 3(1978), pp.337-345, here pp.339-343 and part II, 2(1979), pp.243-249, here pp. 245-247. 
proportional system based on regional party lists. After extensive deliberations, a free parliamentary vote decided the matter in favour of the first-past-the-post system. An exception was made for Northern Ireland, for which the so-called single transferable vote system was proposed that was normally applied in this region for local elections to make sure the Catholic minority would be represented too. ${ }^{21}$

It was, however, not only the electoral system that caused debate in the member states; sometimes, the very principle of having the elections was highly controversial too. With the exception of the German Bundestag, there was some parliamentary opposition against this principle in every national parliament, but most of the time, this concerned radical left-wing minority parties only. Communist and other parties at the extreme left of the ideological spectrum typically regarded the European Community (EC) as a pillar of capitalism that should be contested rather than supported. ${ }^{22}$ In the words of a Communist spokesperson in the Luxembourgian Chamber of Deputies, multinationals and finance groups had taken over the 'island of well-being' that had initially been created in Europe, thus posing a threat to social and democratic achievements. ${ }^{23}$ Hence, according to these groups, any initiative coming from the EC should be distrusted, even if it was presented as a democratic proposal.

In three member states, the principle of European elections met with more than just minority opposition, and these were exactly the ones that had also caused trouble during the intergovernmental negotiations on the European Elections Act. As was mentioned above, France had obstructed any progress on the issue for years. The other two were the United Kingdom and Denmark, which both joined the EC in 1973. Dissatisfaction in the United Kingdom about the terms of entry had led to renegotiations and a popular referendum on the British EC-membership. As a consequence, the United Kingdom initially decided to reserve its position; it did not want to commit itself to European elections until the outcomes of the renegotiations and the referendum were known. ${ }^{24}$ Denmark's hesitations came to expression when it attached two reservations to the 1976 agreement concerning European elections: it wanted a compulsory dual mandate for Danish representatives and demanded that European elections would always be coordinated and held together with its national elections. ${ }^{25}$

In spite of its formal reservations, European elections legislation passed the Danish parliament without any serious problems. EC scepticism was deeply-rooted

21. M. HAGGER, The United Kingdom: the reluctant Europeans, in: V. HERMAN, M. HAGGER (eds), op.cit., pp.204-238, here pp.219-226; J. FORMAN, Preparations for direct elections in the United Kingdom, in: Common Market Law Review, 3(1978), pp.347-357, here pp.351-355.

22. The only exception were the Italian Communists, who had begun to support European integration in the early 1970s. See: M. COTTA, op.cit., p.152.

23. M.A. WING, A big issue in a small state, in: V. HERMAN, M. HAGGER (eds), op.cit., pp.168-182, here p.174.

24. V. HERMAN, op.cit., pp.22-23; D. GOWLAND, A. TURNER, A. WRIGHT, Britain and European integration since 1945. On the sidelines, Routledge, Abingdon, 2010, pp.78-81.

25. T.L. SCHOU, Denmark: the functionalists, in: V. HERMAN, M. HAGGER (eds), op.cit., pp.54-76, here p.66; C. GULMANN, P. VESTERDORF, Preparations for direct elections in Denmark, in: Common Market Law Review, 1(1979), pp.119-126, here p.120. 
in this country, and especially the internally divided Social Democrats were displeased that direct European elections were introduced so quickly after Denmark's entry into the Community. Yet, in spite of critical voices, there was a clear parliamentary majority in favour of the elections which even forced the government to withdraw its initial reservations. ${ }^{26}$ In the United Kingdom and France, the situation was more complicated. In both countries, the government was confronted with a split in the majority. In the United Kingdom, the division between the elections' supporters and opponents ran right through the major parties. Especially in the Labour Party, the group of EC antagonists was strong and could not easily be ignored. They even included some members of the cabinet. Parliamentary opposition was so intense that the government did not see any other option than to introduce a 'guillotine motion' to restrict the duration of the debate and to put an end to filibustering. ${ }^{27}$

In France, opposition came mainly from the Gaullist and the Communist Party. In particular Michel Debré, a prominent and hard-line Gaullist politician, gave the government a hard time. He publicly announced his intention to block the elections almost immediately, and in parliament, he did not allow any opportunity to pass without attempting to realize just that. As in the United Kingdom, the French governments also had to resort to coercive procedural devices to ensure the passage of the legislation. It declared the ratification bill an issue of confidence to get it through parliament, which meant that unless a censure motion were tabled within twenty-four hours, it would automatically become law. ${ }^{28}$ Hence, even though all member states were able to successfully conclude the legislative procedures that were necessary for direct pan-European elections, in two out of nine member states extraordinary methods needed to be deployed to make that happen. This indicates that, in the view of at least a part of the politicians, something important was at stake.

\section{The nature of the European Parliament}

The way members of parliament (MPs) thought about the question what the European Parliament was or should become was closely related to the ideas one had about European integration in general. Roughly speaking, three approaches could be discerned: a federalist, a functionalist and an intergovernmental approach. Those who wanted the European Community to become a federation strove for a strong European Parliament that resembled the national parliaments, but those who preferred to see the Community as an intergovernmental organization felt the European Parliament should have no more than some limited advisory and control functions and empha-

26. T.L. SCHOU, op.cit., pp.64-72; C. GULMANN, P. VESTERDORF, op.cit., pp.119-122.

27. M. HAGGER, The United Kingdom ..., op.cit., pp.208-217 and 223.

28. D. REMY, K.-H. BUCK, France: the impossible compromise or the end of majority parliamentarism?, in: V. HERMAN, M. HAGGER (eds), op.cit., pp.99-125, here pp.103-115; D. SIMON, Preparations for direct elections in France, in: Common Market Law Review, 1(1979), pp.127-138, here pp.131-132. 
sized the role of the member states and their respective parliaments. In the functionalist approach, democratic control was no priority. Functionalists favoured pragmatic solutions for clearly defined problems and a non-political form of European administration. ${ }^{29}$ A role for the European Parliament could be an option, but as compared to the aim of concrete functional achievements, it was of secondary concern only. ${ }^{30}$

In the institutional set-up of the ECSC, the latter approach prevailed. In the period shortly after the Second World War, there was distrust of any form of mass mobilization and the 'technocratic democratic culture' that characterized the organization perfectly matched these feelings. ${ }^{31}$ As more powers were pooled or delegated to the European level, traditional channels of interest representation and accountability were, however, challenged and a legitimacy deficit started to be felt. ${ }^{32}$ One partial solution could be to organize direct elections for the European Parliament. But what kind of parliament could and should that be, according to national MPs? Did it have the potential to develop into a real parliament? And was that a desirable thing to happen anyway, or rather something that should be prevented at all costs?

Especially in the more supranationally minded member states, many MPs hoped that direct elections would result in increasing powers for the European Parliament. All three party groups in the German Bundestag wholeheartedly supported the Parliament's further development. The words of the Social Democratic spokesperson adequately expressed what was generally felt among German MPs:

'The European Parliament must set itself a political objective - and I hope we all support this - to be representative of the peoples of Europe [...] No other bureaucratic organ in the European Community may hinder the institution European Parliament to take over the rights of a full Parliament and exercise it. This is our goal' ${ }^{33}$

In the Benelux countries and Italy, this was the majority point of view too. Yet, even in the United Kingdom, there were MPs who openly expressed their support for a

29. G. BRUNN, op.cit, pp.49-50; J. SMITH, Europe's elected parliament, Sheffield Academic Press, Sheffield, 1999, p.27.

30. M. BURGESS, Federalism and the European Union: the building of Europe, 1950-2000, Routledge, London, 2000, pp.117-118.

31. M. CONWAY, V. DEPKAT, Towards a European history of the discourse of democracy: discussing democracy in Western Europe, 1945-1960, in: M. CONWAY, K.K. PATEL (eds.), Europeanization in the twentieth century: historical approaches, Palgrave Macmillan, Basingstoke, 2010, pp. 132-156, here pp.139-141.

32. Q. JOUAN, Narratives of European integration in times of crisis: images of Europe in the 1970s, in: Journal of European Integration History, 1(2016), pp.11-28, here pp.21-22; B. RITTBERGER, op.cit., pp.4-6.

33. Proceedings of the German Bundestag, 26.05.1977. Each national parliament has its own specific reference system. Often one needs to be or become familiar with these systems to be able to use them well. In fact, with many parliamentary documents published on the internet, nowadays, one can often more easily find the right parliamentary documents by a search on date. Therefore, the documents of the nine parliaments that were used for this article are all referred to in a similar manner: the name of the House or parliamentary Committee is mentioned first, followed by the date of the meeting referred to. 
stronger European Parliament. The words of William Hamilton, a member of the House of Commons and the European Parliament for Labour, clearly illustrate this:

'It has been argued that this measure is a step on the road to federalism. I do not mind if it is. Indeed, I think that it might be. I am not objecting to it. Federalism is not a dirty word. The inevitable and desirable consequence of democratic elections to the European Assembly will be that its members will demand, and get, more power' ${ }^{34}$

Hence, MPs who supported the elections and who envisioned the European Parliament to develop into a fully-fledged parliament did not only hope that the elections would empower it, they also expected this to happen. They realized that elections per se would not give Parliament additional powers, but at least an important precondition for acquiring them would be fulfilled. With a direct mandate from the people, MEPs would have greater authority and since most of them would probably be fulltime members, they would also have more time to commit themselves to the cause. Even though the elections were no more than a first step in the right direction, in the long run, the process of transforming the European Parliament into a serious democratic counterforce would appear to be irreversible. ${ }^{35}$

Many of the elections' fiercest opponents shared this expectation; they saw the elections as a step on the road to European federalization. The European Parliament's increased authority would lead to greater competences, which would legitimize the European Commission and weaken the Council of Ministers. This would all contribute to a federal Europe, which was exactly what they did not want. A Labour Member of the British House of Commons warned: '[i]n accepting direct elections, we shall be on a very slippery slope to a federal State'. ${ }^{36}$ This was also the opinion of the EC-critical Socialist People's Party in Denmark:

'direct elections to the European Parliament are a part of, a chip in creating the European Union. [...] If we support direct elections, we insert a chip which will be used later when the Union is constructed'. ${ }^{37}$

In spite of their proclaimed international orientation, Communist minority parties in several member states fulminated against the risk of losing national independence too. They expected that in a federal Europe, trade and industry would run the show, probably supported by the Federal Republic of Germany, a country which was still deeply distrusted in these circles. According to a spokesperson of the Belgian Communist Party, right-wing European politicians - 'les Straus et consorts' - would dominate the European Parliament and the European Community. These people would seek to encroach more and more of the sovereignty of the member states and their respective parliaments, in particular with a view to prevent the exercise by one

34. Proceedings of the British House of Commons, 06.07.1977.

35. See, for instance: Proceedings of the Dutch House of Representatives, 22.06.1977; Proceedings of the Dutch Senate, 28.06.1977; Proceedings of the Belgian House of Representatives, 08.12.1977; J. THILL, Preparations for direct elections in the Grand Duchy of Luxembourg, in: Common Market Law Review, 4(1978), pp.473-478, here pp.473-474.

36. Proceedings of the British House of Commons, 29.03.1976.

37. Proceedings of the Danish Parliament, 11.12.1975. 
or more of the peoples concerned of their inalienable rights to serious political and economic reform. ${ }^{38}$

Curiously enough, the conviction that the European Parliament would not gain powers and remain a weak and ineffective institution was also put forward as an argument against its direct election. Sceptical remarks by a conservative British MP clearly illustrate this:

'I just wonder what the extra 200 Members of Parliament will do when they get there with their lovely researchers and lovely secretaries and lovely expenses allowances. What will they do which the 198 cannot do at the moment? We understand that they will not get any extra powers, so what will they do? Obviously they will produce plenty more paper and more advice which no one listens to'. ${ }^{39}$

The Dutch Communists did not put any trust in the European Parliament's ability to control anything either. According to them, the elections had nothing to do with democracy; they were fake elections for a fake parliament. ${ }^{40}$ Sometimes, critical MPs also combined the two contradictory arguments. According to a British MP who belonged to the anti-market group in the Labour Party,

' $[\mathrm{t}] \mathrm{he}$ simple truth is surely that either this proposed Assembly will have some real power, in which case adherence to it is a step towards some sort of federal State and a loss of real independence by this country, for which the electorate has not voted. Or else it will not have real power, in which case it is a waste of time and a good deal of public money. That is the fundamental dilemma which it seems to me so many propagandists have been trying to conceal from the public'. ${ }^{41}$

In member states where the elections were controversial, statements like these were made also in reaction to reassuring words by ministers and other politicians who wanted to gain parliamentary approval for the elections. Any sign of agreement with more ambitious ideas concerning the European Parliament's future would be pouring oil to the fire and complicate the situation. Hence, in the United Kingdom as well as in Denmark and France, government spokespersons confirmed - partly out of conviction, partly for strategic reasons - that the elections could never lead to any automatic or unauthorized additional competences for the European Parliament. In Denmark, the Minister for Market Affairs, Ivar Nørgaard, declared in advance: '[t]he introduction of direct elections will not - and I stress not - alter the balance of competencies between the Parliament and the Council'. ${ }^{42}$ A treaty change would certainly be necessary to change the parliament's competences. ${ }^{43}$

38. Proceedings of the Belgian House of Representatives, 08.12.1977.

39. Proceedings of the British House of Commons, 12.07.1976.

40. Proceedings of the Dutch House of Representatives' Committee for Foreign Affairs, 21.03.1977; Proceedings of the Dutch House of Representatives, 22.06.1977.

41. Proceedings of the British House of Commons, 12.07.1976. For another example, see: Proceedings of the British House of Commons, 25.04.1977.

42. Proceedings of the Danish Parliament, 11.12.1975.

43. T.L. SCHOU, op.cit., p.71. 
In the United Kingdom and France, political statements were not sufficient to calm tempers. To meet the objections of the elections' adversaries, additional articles were included in the legislation to secure the national parliament's right to have the final say in these matters. The French clause determined that '[a]ny alteration in the powers of the Assembly of the European Communities [...] shall be null and of no effect as regards France' if it had not been submitted for approval in the French parliament. ${ }^{44}$ The British article read:

'No treaty which provides for increases in the powers of the Assembly shall be ratified by the United Kingdom unless it has been approved by an Act of Parliament'. ${ }^{45}$

The majority that supported the latter article was overwhelming and included pro- as well as anti-market MPs, thus demonstrating that supporting the principle of European elections could but did not necessarily imply support for the European Parliament's autonomous development into a fully-fledged parliamentary organ. ${ }^{46}$

\section{Relations between the European Parliament and national parliaments}

The discussion on the European Parliament's potential and future powers was closely related to the question of the relationship between the European Parliament and national parliament. The federalist inspired point of view which was clearly present in, for instance, the Dutch parliament, was that the transfer of executive powers to the European level should go hand in hand with the awarding of parliamentary competences to the European Parliament. In policy areas that could no longer be controlled by national parliament, the European Parliament should take over its parliamentary duties.

If this theory would become practice, the ultimate consequence would of course be that national parliaments would become less important. Depending on the scope of the issue areas that would be brought into the integration process, in the long run national parliaments might either become junior partners in a collaboration with the European Parliament or even become superfluous. Nonetheless, in Dutch parliament, the concern of EC-critical minority parties that the elections would create competing democratic mandates and would thus be detrimental to the position of national parliament, was skimmed over. According to Schelto Patijn, a Dutch MP for the Social Democratic Party and author of the 1975 EP report on direct elections, the idea that the European Parliament would be the national parliament's rival was a misconception. Whereas the latter would continue to control the national government, the Euro-

44. The article also made mention of a decision by the Constitutional Court on this matter. For an extensive analyses of the decision, see, for instance: J. PRILLEVITZ, Het besluit over de Europese verkiezingen II, in: Nieuw Europa, 1(1977), pp.20-24.

45. V. HERMAN, J. LODGE, Direct election: outcomes and prospects, in: VALENTINE HERMAN and MARK HAGGER (eds.), op.cit., pp.239-259, here p.251.

46. M. HAGGER, Towards a comparison ..., op.cit., p.227. 
pean Parliament's efforts would be directed towards the European institutions. In his view, national parliaments and the European Parliament would thus be 'on the same side, the side of democratic control of power', ${ }^{47}$

In the British House of Commons, some of the EC's strongest supporters made similar reassurances. Douglas Hurd (Conservatives) expected that there would be 'a certain creative jealousy' between the institutions, but he did not see how this would lead to the draining away of the authority of the House of Commons. ${ }^{48}$ David Steel (Liberals) also considered the European Parliament as an additional rather than competing democratic force:

'[w]hat we are doing is enlarging the capacity of the people to control the bureaucracy.

We are giving them a double-barrelled shotgun instead of a single-barrelled one' ${ }^{49}$

However, in the United Kingdom, this line of reasoning was less easily accepted. Here, national parliament was much more than the institutional manifestation of the country's democratic system; according to one MP, Westminster was in fact 'the expression of our nationhood' ${ }^{50}$ Even among the elections' advocates, there were not many who would be prepared to give up any of Westminster's democratic prerogatives.

In Denmark, the relation between the European Parliament and national parliament was one of the major subjects of discussion. The reservations that the Danish Social Democratic government had introduced at the European level were clearly meant to accommodate critical voices within the party's own ranks and to prevent the powerful People's Movement against the EC outside parliament from running for the European elections. ${ }^{51}$ But they were also seen as a kind of control mechanism visà-vis the European Parliament. According to its spokesperson, the Social Democratic Party wanted a compulsory double mandate

'to safeguard accordance between the position of the Danish Parliament and the points of view represented by the Danish members of the European Parliament'. ${ }^{52}$

Even when the reservations were withdrawn most Danish MPs were satisfied that it would remain possible to combine a seat in the national parliament with a seat in the European Parliament. All agreed that it was paramount to secure an intimate coordination between the MPs' and MEPs' positions. ${ }^{53}$

Since the European Council had failed to take a clear decision on the subject, the dual mandate was a topic of discussion everywhere. It was obvious that an obligatory dual mandate could not easily be reconciled with the Act's objectives: if MEPs would

47. Proceedings of the Dutch House of Representatives' Committee for Foreign Affairs, 21.03.1977.

48. Proceedings of the British House of Commons, 30.03.1976.

49. Ibid.

50. Proceedings of the British House of Commons, 06.07.1977.

51. T.B. OLESEN, Anker Jørgensens tid 1972-1982, in: De Danske Ministerier, GAD Publishers, Copenhagen, 2017, p.269.

52. Proceedings of the Danish Parliament, 11.12.1975.

53. Proceedings of the Danish Parliament, 20.10.1977. 
need to be replaced after they had lost their seat in national parliament, the composition of the European Parliament would continue to depend on other factors than the people's direct vote only. For practical reasons, even an optional dual mandate could be considered problematic. In a number of parliaments, proposals were made to completely prohibit dual representation. As a spokesperson of the Belgian Social Democratic Party explained, the European Parliament should have 'full-fledged European parliamentarians' ${ }^{54}$ Even though the trouble of having to travel long distances was less problematic for Belgian than for other member states' politicians, it would still be very difficult to focus simultaneously on the work in two parliaments. Each parliament deserved full-time members. In principle, the Belgian government shared this viewpoint, but 'in order not to sever the relations between both elective bodies', it believed that it would be better if a combined mandate remained possible, at least for the first term of office. ${ }^{55}$ Germany and Italy stuck to the optional dual mandate for similar reasons. An additional argument was that prominent national politicians should be given the opportunity to stand for European elections, because it could be helpful for the Parliament's prestige among the public and with other European institutions. ${ }^{56}$

Eventually, none of the member states prohibited or required a dual mandate, not even in Denmark where the government finally capitulated on this issue in 1977.57 Therefore, it was left to political parties to decide whom they wanted to nominate. This implied that after the elections, guaranteed connections between the two parliamentary levels would cease to exist, thus confronting the parliaments with the question how contact between MEPs and MPs could be facilitated. A Dutch MP of the progressive Liberal Party (D66) warned that if no links were established between the members of the European Parliament and national parliament, there would be a danger that MEPs would lose touch with the national basis on which their powers still rested and 'fly into a European dream world', while national parliament might, on the other hand, be tempted to close its eyes for the European dimension of its work and focus on the national context only. ${ }^{58}$

In several member states, suggestions were made to create a special status for MEPs who were not sitting in national parliament. In the Italian parliament, it was proposed to admit MEPs to sit in national parliament without the obligation to participate in the work of its committees and with the quorum rules being unaffected by their presence or absence. ${ }^{59}$ In Ireland, a proposal was tabled to give MEPs a right of audience in both Houses of parliament, and in appropriate committees of both Hous-

54. Proceedings of the Belgian House of Representatives, 08.12.1977.

55. L. NEELS, op.cit., part I, p.344.

56. F. SAVERIO BAVIERA, Preparations for direct elections in Italy, in: Common Market Law Review, 2(1978), pp.199-206, here p.200; M. BANGEMANN, part I, op.cit., p.326.

57. T.B. OLESEN, op.cit., p.270.

58. Proceedings of the Dutch House of Representatives' Committee for Foreign Affairs, 21.03.1977; Proceedings of the Dutch Senate, 28.06.1977; Proceedings of the Dutch House of Representatives, 29.08.1978.

59. F. SAVERIO BAVIERA, op.cit., p.200. 
es. ${ }^{60}$ Two Dutch MEPs were of the opinion that MEPs should be given full parliamentary membership, except only for the right to vote. ${ }^{61}$ In a report by the House of Lords, it was suggested not to give MEPs any actual membership of national parliament, but to create a new 'European Grand Committee' composed of all British MEPs, all members of the existing scrutiny committees for European law of both Houses and their subcommittees, and perhaps other MPs as well. ${ }^{62}$

All in all, the details of the propositions clearly differed from each other, but what they all had in common was that they took a continued MEP connection to national parliament as a starting point for their ideas, thus implying that it were the MEPs who were ultimately responsible for keeping in touch. The idea that national MPs might just as well visit their European colleagues and attend their meetings did not occur. The only exception was a bill that was discussed in the French parliament just a few days before the European elections. It was drawn up by the Gaullist group and aimed to restore the position of the French parliament by improving information supply from the European Parliament to both Houses of the French parliament. Even though it was not accepted in its original form, a small delegation of MPs was founded that was to transmit documents and files from Strasbourg to Paris. ${ }^{63}$

\section{The nature of representation}

Another issue that was evidently connected to the question of the European Parliament's nature and its relation to national parliament was the question of the MEP's mandate. Even until today, its nature cannot be unequivocally specified. Due to different parliamentary traditions, perceptions of what representation is about vary. And there is no undisputed answer to the question whether MEPs collectively express the sum of general national interests or the common interests of the European people. ${ }^{64}$ In the run-up to the first elections, these issues were debated too. Whom should the MEPs represent? Should they primarily act as Europeans? Or were they sitting in the European Parliament mostly to defend national or regional interests?

In the existing situation, MEPs were organized according to political affiliation and not by nationality, thus downgrading the relevance of the MEPs' national background. This was unreservedly applauded by a parliamentary majority in Germany, Italy and the Benelux countries. As a matter of course, the federalist body of ideas started from the premise that the Community's institutions would be or at least become truly European bodies. MEPs were thus expected to transcend the national

60. M. ROBINSON, Preparations for direct elections in Ireland, in: Common Market Law Review, 2(1978), pp.187-198, here p.189.

61. R. BOSSCHER, Preparations for direct elections in France, in: Common Market Law Review, 4(1978), pp.465-472, here p.472; R. VAN SCHENDELEN, op.cit., p.191.

62. J. FORMAN, op.cit., p.238.

63. Proceedings of the French House of Representatives, 31.05.1979.

64. O. COSTA, Parliamentary mandate, in: Y. DÉLOYE, M. BRUTER (eds), op.cit., pp.375-378. 
interest and to think and act like Europeans. According to a Dutch MP for the Christian Democratic Party, supranational policies required supranational assessments, and therefore, the European Parliament should be more than 'the sum total of the parts'. ${ }^{65}$ The creation of transnational parties could contribute to this. Their development had been stimulated by the coming elections, which several Belgian and German MPs, among others, welcomed as a much-desired development for truly European policies. ${ }^{66}$

However, it was evident that in the European Elections Act, a different emphasis could be distinguished too. Whereas the MEPs' designation as 'representatives [...] of the peoples of the States brought together in the Community' could still be interpreted in a pan-European way, the article that arranged for the division of seats among the member states inevitably made clear that nationality was still a relevant factor. ${ }^{67}$ And in a number of member states, it was indeed beyond doubt that their MEPs should primarily represent their own nationals. In France, the whole debate about the European elections was impregnated with an overall and continuous focus on French sovereignty and identity. In this respect, there was hardly any difference between those supporting and those opposing the elections. ${ }^{68} \mathrm{~A}$ statement by a representative of the Centrist Union group clearly illustrates this. He expected a positive effect from the European elections, because 'through the elected eighty-one', not only the French government, but also the French people could 'make their voice heard in the new democratic European concert'. If they stood united, this would guarantee the 'liberty and security of the French' ${ }^{69}$ The government's choice to deviate from its national practice of multiple constituencies and to create one single French constituency for these elections was inspired by a similar point of departure: if the elected MEPs were to represent the French people, it would be best for them to be appointed at the national level too. It was important to underline French national unity, not only against panEuropean initiatives, but also against independence movements in Brittany, Corsica and the Basque region, who could use the European Parliament as a platform for realizing their ideals. ${ }^{70}$

In the Irish parliament too, the paramount importance of Irish MEPs defending Irish interests was continuously brought forward. On the face of things, the unproblematic passage of the European election law gave the impression of a very Europeanminded attitude, which was in fact what Irish politicians consciously aimed at. However, in reality, European funding and help were the first matters of importance. ${ }^{71}$

65. Proceedings of the Dutch House of Representatives' Committee for Foreign Affairs, 21.03.1977.

66. See, for instance: Proceedings of the Belgian House of Representatives, 08.12.1977 and 10.07.1978; Proceedings of the German Bundestag, 26.05.1977 and 16.03.1978.

67. See: article 1 and 2 of the Act concerning the Election of the Representatives of the Assembly by Direct Universal Elections.

68. See, for instance, a comment by Louis Weiss in Le Monde, 14.04.1979. Cited in: F. DE LA SERRE, M.-C. SMOUTS, G. BIBES, H. MENUDIER, Convergences nationales, dimensions partisans et affinités croisés, in: Revue française de science politique, 6(1979), pp.1014-1046, here p.1002.

69. Proceedings of the French House of Representatives, 14.06.1977.

70. D. SIMON, op.cit., p.135; J. PRILLEVITZ, op.cit., p.23.

71. See, for instance: Proceedings of the Irish House of Representatives, 26.10.1977 and 27.10.1977. 
Irish MEPs were supposed to help the government and bring prosperity to Ireland. A representative of the conservative Fine Gael Party stated, for instance:

'I see nothing wrong with Ministers, who are in the Council of Ministers, calling their members of the European Parliament together and saying "This is my line". ${ }^{72}$

According to a fellow party member, political affiliation should be subordinated to the national interest:

'We will be contesting this election under party political banners and, when the posters are taken down after the election, I hope the 15 people who will go to Europe will look after the interests of the people of Ireland in a united manner'. ${ }^{73}$

Except from some lone voices, British MPs did not usually think of MEPs as representatives of European interests either, but their point of view was different from that of most French and Irish politicians. In the United Kingdom, there was a strong tradition of seeing MPs primarily as representatives of their constituencies. Hence, said a representative for Labour, the most natural thing for a MEP to do was not to defend the European or even national interest, but to represent his region. Even loyalty to his own party or his own voters was of secondary importance. A Conservative member of the Commons aptly put it as follows:

'I hold strongly to the notion that a Member of Parliament, whether for Westminster or Europe, represents and should be open to all those living in his area. I find it very distasteful to imagine sitting as a member $[\ldots]$ and $[\ldots]$ having only those people who have voted for me coming to see me'. ${ }^{74}$

Relatively strong traditions of subnational representation existed also in the Federal Republic of Germany and in Belgium. In the Federal Republic of Germany, pressure to ensure that MEPs would also be seen as spokespersons of the Länder came to the surface mostly in the Bundesrat (a legislative body that represents these states at a national level). Especially the representatives of the smaller German states were afraid that they would be under-represented at the European level, but proposals that would give them guarantees were rejected. ${ }^{75}$ Reconciling this mode of thinking with prevailing pan-European convictions required an inventive mind. Yet, the most evident example of conflict between subnational interests and supranational ideals was clearly the Belgian debate, which made an almost schizophrenic impression. Whereas the Belgian government had generously yielded one of its seats to the Greenland people of Denmark to save the international negotiations on the European Elections Act, among each other the language groups begrudged each other every possible advantage..$^{76}$ Whereas the coming European elections were celebrated as a historical moment, finally allowing the European peoples to choose who would be "their com-

72. Proceedings of the Irish House of Representatives, 27.10.1977.

73. Proceedings of the Irish House of Representatives, 26.10.1977.

74. Proceedings of the British House of Commons, 13.12.1977.

75. J. LODGE, Germany: Modell Deutschland, op.cit., pp.84, 90 and 94.

76. P.H. CLAEYS, E. DE GRAEVE-LISMONT, N. LOUB-MAYER, Belgium, in: K. REIF (ed.), op.cit., pp.37-50, here p.39. 
mon representatives', a clause was inserted in the Belgian election law to guarantee that those who would enroll for the Dutch electoral college were indeed Dutchspeaking and those who would be nominated for the French electoral college would be either French- or German-speaking. ${ }^{77}$

\section{The nature of the voter}

Even though the Belgian situation may stand out as an example illustrating the paradoxes that were present in national parliamentary debates about the European elections, twisted arguments could definitely be found in the other member states too. Especially questions concerning the nature of the voters and their relation to the European institutions appeared to lead to ambiguous answers and solutions.

For those who took a functionalist or intergovernmental view of European integration, it was sufficient for Europe to remain 'a legal fact, resting on a treaty and sustained by the "we" of politicians, civil servants and lawyers'. In this view, the general public would not need to become 'Europeans'. The federalist conviction was exactly the opposite: a political union required a European public arena, and thus truly European citizens. ${ }^{78}$ It was believed that once people would get used to participation in direct European elections, this would stimulate the emergence of a European mentality and create a collective political identity ${ }^{79}$ A representative of the Social Democratic Party in the Belgian House of Representatives believed that now that elections were held, a 'European awareness' was indeed in the making. ${ }^{80}$ The major representative of Italian Europeanism, Altiero Spinelli, even went so far as to claim in his parliament that the elections could in fact be seen as the "birth certificate of the "European people". .81

However, a shared popular feeling of being Europeans would still be in the future, because in practice, people were not yet familiar with either European policies or any of the EC institutions, and legally speaking, European citizenship did not exist either. In 1975, the European Council had commissioned Belgian Prime Minister, Leo Tindemans, to write a report and to reflect on what could be understood by the term 'European Union'. The brief included the question what specific European rights could be attributed to the member states' citizens, but soon, it appeared that these rights were no priority issue: the report's recommendations were put under a big pile

77. Proceedings of the Belgian House of Representatives, 08.12.1977. See also L. NEELS, op.cit., part I, p.343.

78. L. VAN MIDDELAAR, op.cit., pp.215 and 221.

79. E. O'CONNOR, A salutary shock: the European suffrage movement and democracy in the European Community, 1948-1973, in: Journal of Contemporary European Research, 1(2014), pp.58-73, here pp.60-61 and 71 .

80. Proceedings of the Belgian House of Representatives, 08.12.1977.

81. Proceedings of the Italian House of Representatives, 10.02.1977. 
of paper. ${ }^{82}$ European citizenship remained mostly a 'market citizenship', organized around the Rome Treaty's provisions on free of movement for workers in the European Community. ${ }^{83}$ Even though it would seem logical that people who had moved to other EC member states to work there, would be given the right to vote and to stand for election, in practice, it appeared to be difficult to guarantee that this would indeed be the case. Contrary to the 1960's Dehousse proposal, neither the European Parliament's eventual proposal, nor the final Act, contained any obligations in this regard. ${ }^{84}$

The question whether the European character of these elections required adjustments to the voting and eligibility rules that were normally applied was discussed in almost every national parliament, but the solutions differed. As long as the elections were held separately in the individual member states, there were basically two ways to give the vote to broader groups of people than national residents: nationals emigrated to another member state could be allowed to vote in the state of origin (nationality principle) or immigrated nationals of other member states could be given the franchise in the state of residence (territoriality principle). Or it could of course be decided to apply neither of these principles at all. In spite of its generally proEuropean attitude, this was what Luxembourg did. The United Kingdom did not enfranchise new groups of people either, although Irish people who were living in the United Kingdom as well as British civil servants working abroad already had a right to vote.

Apart from these two, other member states made adjustments to existing election laws. The details of the rules differed, but most governments chose to employ the nationality principle. ${ }^{85}$ Especially in Italy, voting rights for emigrants were a matter of profound discussion, although it did not seem to be inspired by European convictions only. With about 1,800,000 Italian migrants working in other EC countries, a relatively large group of people was involved. ${ }^{86}$ For the Communist Party it was not attractive to give them the right to vote, mainly out of fear of not getting a fair chance to pull votes in countries where Communist Parties were politically irrelevant, were forbidden or did not exist for other reasons ${ }^{87}$ Other parties, on the other hand, considered it of great importance to give emigrants the right to vote. Especially the Italian Socialist Movement fought a harsh battle; according to its spokesperson denying emigrants the right to vote could be seen as a kind of 'electoral genocide'. ${ }^{88}$ Even-

82. A.G. HARRYVAN, J. VAN DER HARST, Victimized by Euroscepticism. European citizenship in the Dutch political discourse, in: Journal of European Integration History, 2(2016), pp.313-328, here pp.313-314.

83. R. BELLAMY, D. CASTIGLIONE, J. SHAW, Introduction: from national to transnational citizenship, in: R. BELLAMY, D. CASTIGLIONE, J. SHAW (eds), Making European citizens. Civic inclusion in a transnational context, Palgrave Macmillan, Basingstoke, 2006, pp.1-28, here p.10.

84. F. SAVERIO BAVIERA, op.cit., pp.201-202.

85. V. HERMAN, J. LODGE, op.cit., pp.246-248.

86. F. SAVERIO BAVIERA, op.cit., p.201.

87. M. COTTA, op.cit., p.162.

88. Proceedings of the Italian House of Representatives, 17.01.1979. 
tually, it was decided to give emigrants voting rights, but only as long as equal campaigning rights were guaranteed. ${ }^{89}$

The territoriality principle was applied in two member states only. In light of the Irish interpretation of an MEP's job (defending the Irish interest), it is remarkable to note that Ireland consciously opted for what it considered the most European option: all nationals of EC member states who were living in Ireland were given the right to vote. 'It is possible that very few votes will be at stake, but the principle is important', said one of the spokespersons in the debate on the election bill. ${ }^{90}$ Without any doubt, the most European-minded regulations were, however, adopted in the Netherlands: Dutch nationals who were resident in another EC member state would get the vote as well as nationals of other EC member states who were living in the Netherlands and who were not enfranchised by their country of origin. The arrangement caused complications, because it required rules that would prevent certain groups from voting twice, but the Dutch government felt obliged to try and make sure that as many people as possible could vote.

The Dutch government had also considered the possibility to give inhabitants with the nationality of other member states eligibility for elections, but because the national element was still predominantly present in the Act, it had eventually decided not to do so. ${ }^{91}$ MPs agreed: once a uniform election system was established, truly European lists of candidates would be appropriate, but in this transition period, national lists of candidates were a logical choice. ${ }^{92}$ Besides, neither of the other member states made such arrangements. Whereas groups of MPs made pleas to Europeanise the franchise and give the vote to broader groups of people in several national parliaments, a strictly national approach to the question who could stand for election was generally accepted.

Even though suffrage and eligibility rights no more than partially underpinned the idea of a European demos, many of the elections' proponents expected and hoped that they would at least stimulate public interest and increase the average citizen's involvement with integration policies. In the words of an Irish MP:

'The forthcoming European Assembly elections will be a very effective means of bringing home to our people what the EEC is all about. I believe this will lead to a better understanding of the EEC, a better appreciation by our people of what is involved'.$^{93}$

The same type of argument was likewise a standard in the repertoire of the pro-EC Danish parties. ${ }^{94}$ This bigger picture was also sketched by Luxembourg's Prime Minister Gaston Thorn when he said: 'the path to European unification now lies open

89. M. COTTA, op.cit., p.163.

90. Proceedings of the Irish House of Representatives, 26.10.1977.

91. Explanatory memorandum to the Dutch European Elections Bill (15 044, no.3); Government answers to the written comments on the Dutch European Elections Bill $(15044$, no.6).

92. Written comments on the Dutch European Elections Bill (15 044, no.5).

93. Proceedings of the Irish House of Representatives, 27.10.1977.

94. Proceedings of the Danish Parliament, 11.12.1975 and 20.10.1977. 
to a citizen's Europe alongside the Europe of states' ${ }^{95}$ Yet, in spite of these idealistic overtones, from a democratic point of view, there were some snags, and critical remarks were bound to come.

First of all, the distribution of the seats as laid down in the European Elections Act, advantaged the smaller states at the expense of the bigger ones in terms of population size. As a result, on average, a Luxembourgian MEP represented 59,500 people, whereas a German or an Italian MEP respectively represented 765,938 and 683,469 people. ${ }^{96}$ As one Christian Democratic MP correctly remarked in the German Bundestag, this was 'very, very far away from the principle of equality of votes' ${ }^{97}$ The unequal distribution of seats also led to dissatisfaction on the part of representatives of Scotland and Wales. Because the population of the United Kingdom was relatively under-represented in the European Parliament, their population was too. 'The situation is profoundly unsatisfactory', argued a representative of the Scottish National Party:

'Scotland and Denmark have populations of the same size, yet Denmark has double the representation. Southern Ireland has half the population of Scotland, yet it gets 15 seats. [...] Scotland is an old nation, as old as Denmark or Ireland, yet one Scotsman is now apparently worth only one-third of an Irishman or one-half of a Dane' ${ }^{9}{ }^{98}$

Another element that was approached critically, especially in member states that were used to a constituency voting system, was the distance between a representative and his voters. In all member states, the number of seats to be distributed in the elections was much lower than for national general elections, as a consequence of which each representative was representing a larger number of people than everyone was accustomed to. As an Irish MP pointed out to his colleagues, the voters of constituencies of the size that were proposed for these elections would not really know the candidates. ${ }^{99}$ 'What form of meaningful contact or representation can there be between a member and his voting constituents - numbering about 600,000 - and a population of nearly 1 million?', asked a Labour MP in the British House of Commons.

'How will constituents get in touch with their member? How will the member find out what his constituents think? In representative terms, it is a piece of democratic nonsense'. ${ }^{100}$

Finally, the question was justifiable whether these elections were to be seen primarily as a genuine democratic endeavour to allow people to have a say in European policies, or rather as a carefully-considered attempt to legitimize European policies and to provide the integration process with a shot in the arm. To a certain extent, elections can always be seen as processes of legitimation, but since there was no real power to

95. J. THILL, op.cit., p.473.

96. V. HERMAN, J. LODGE, op.cit., pp.255-256.

97. Proceedings of the German Bundestag, 26.05.1978.

98. Proceedings of the British House of Commons, 02.02.1978.

99. E. MOXON-BROWNE, Ireland: an eager consummation, in: V. HERMAN, M. HAGGER (eds), op.cit., pp.126-143, here p.134.

100. Proceedings of the British House of Commons, 29.03.1976. 
be distributed in the European Parliament, this was even more true for direct European elections. ${ }^{101}$ It was evident that the aim to democratize the European Community was closely linked to the ambition to make progress in the field of European integration. ${ }^{102}$ As one MP in the Italian parliament put it, Europe's vast popular forces could be seen as the 'protagonists' of a 'great leap forward towards European unification'. ${ }^{103}$ The same objective was also clearly noticeable in the parliamentary report of the Luxembourgian House of Representatives, in which the elections were called a dynamic element in the integration process. ${ }^{104}$ 'A whole new dynamism in the European area' and 'an acceleration of the European unity' were also what Christian Democratic members of the Belgian and Dutch parliament hoped for as a result of the elections. ${ }^{105}$

If European elections were to underscore popular support for European integration, this would of course only work when the turnout was high enough to convincingly demonstrate the involvement of the people. Hence, at the European level, an information program was launched to raise awareness of the European Parliament's existence and the coming elections. ${ }^{106}$ Some member states considered this sufficient and did not take any additional measures of their own. In Belgium and Luxembourg, it was not necessary to do so, because voting was compulsory by law. In a country like the United Kingdom, the elections were simply too controversial to launch turnout raising initiatives. Negative comments by MPs calling the European information campaigns politically biased propaganda made it perfectly clear that any government intervention would lead to a renewed political debate between as well as within the parties. ${ }^{107}$

In some member states, national initiatives were taken to stimulate a good turnout for the European elections, for instance in the Netherlands, where a special committee was established to inform and mobilize the voters with a publicity campaign. ${ }^{108}$ In Irish parliament, it was, among others, hoped that the media would provide people with information about the elections and the European Parliament. And naturally, it was also an important responsibility of the parties contesting the elections to convince

101. K. REIF, Ten second-order..., op.cit., p.2.

102. Q. JOUAN, op.cit., p.25; J. SMITH, op.cit., p.56; A. CONNOLLY, S. DAY, J. SHAW, The contested case of EU electoral rights, in: R. BELLAMY, D. CASTIGLIONE, J. SHAW (eds), Making European citizens..., op.cit., p.35.

103. Proceedings of the Italian House of Representatives, 17.01.1979.

104. J. THILL, op.cit., pp.473-474.

105. Proceedings of the Belgian House of Representatives, 08.12.1977; Proceedings of the Dutch Senate, 12.12.1978.

106. J. LODGE, Direct elections to the European Parliament 1984, St. Martin's Press, New York, 1986, pp.18-19.

107. See, for instance: Proceedings of the British House of Commons, 08.02.1978; Proceedings of the British House of Lords, 07.03.1978.

108. W.J.P. KOK, I. LIPSCHITS, P. VAN PRAAG, The Netherlands, in: K. REIF (ed.), op.cit., pp. 153-165, here p.154. 
people to bring out their votes. ${ }^{109}$ A number of German MPs called upon political parties to do their best to motivate the voters. ${ }^{110}$ If they would take these elections seriously, and public relations activities would be organized by the Federal government and the states, there was no reason to be pessimistic about turnout rates. In light of the 'fundamentally positive European spirit' of German citizens, it was expected that they would be willing to go to the polls. ${ }^{111}$

\section{A transnational debate?}

Opinion polls that were held in the build-up to the first European elections, showed that the majority of the member states' citizens were in favour of these elections. ${ }^{112}$ Nonetheless, the eventual turnout of just a little more than 62 per cent must have disappointed those with federalist aspirations; apparently, the public was less European-minded than they had hoped for. But what about the politicians themselves: to what extent could they be seen as 'Europeans'? As a matter of course, parliamentarians were aware of the opinions of colleagues in their own national parliament, but to what extent were they informed about the points of view that were taken in other parliaments?

Soon after the first elections had been held, they were described as 'second order national elections': elections that were not only of secondary importance, but which outcomes were in fact also largely determined by the (primary) domestic political arena. ${ }^{113}$ The term was well-received and many scholars and handbook authors adopted similar terms and frames of research. ${ }^{114}$ In recent literature, the image of European elections as second order national elections has, however, been criticized. The Italian professor of History of International Relations, Daniele Pasquinucci has, for instance, argued that this way of looking at the European elections is too onesided and overlooks pan-European elements that can also be discerned. ${ }^{115}$ And in line with fruitful historical research on the influence of transnational networks on EC policies, historian Eric O'Connor has demonstrated that what can in any case be

109. Proceedings of the Irish House of Representatives, 26.10.1977; Proceedings of the Irish Senate, 07.12.1977.

110. Proceedings of the German Bundestag, 26.05.1977.

111. Proceedings of the German Bundestag, 16.03.1978.

112. V. HERMAN, op.cit., p.29.

113. K. REIF, Ten second-order..., op.cit.

114. See, for instance: Y. MÉNY (ed.), Building parliament: 50 years of European Parliament history, 1958-2008, Luxemburg, 2009, p.37; S. HIX, A.G. NOURY, G. ROLAND, Democratic politics in the European Parliament, Cambridge University Press, Cambridge, 2007, p.28; R. CORBETT, F. JACOBS, M. SHACKLETON, The European Parliament, John Harper Publishing, London, 8th edition, 2011, p.31.

115. D. PASQUINUCCI, Towards an historical approach to the European elections, in: Working Paper AUSE, 03(2008), pp.4-10 and 34-40. (See: http://www.ause.eu/public/medias/ 2008_3_2008_D_PASQUINUCCI.pdf, accessed: 29 July 2016). 
claimed is that activists that called for European elections were part of a 'supranational suffrage movement'. ${ }^{116}$ But can those who opposed them be considered to be part of some kind of supranational network too? And if such networks can be discerned, were members of national parliaments (MPs) participating in these as well?

In any case, it is interesting to note that in the period before European agreement on the elections was reached, members of different national parliaments took the initiative to break the deadlock by making proposals for the unilateral organization of direct elections for their own states' MEPs. A group of national MPs from different member states even discussed their plans at a meeting with the Political Affairs Committee of the European Parliament. This indicates that there were contacts and transnational influences. On the other hand, the fact that these MPs were unable to bridge their mutual differences and did not organize any follow-up meetings to try and make another attempt tells us that the degree of cooperation should not be exaggerated and was limited indeed. ${ }^{117}$ In his well-known work The passage to Europe, Luuk van Middelaar writes:

'Unlike governments, [parliaments] decide neither jointly nor simultaneously. They therefore feel less situational pressure. Several governments have signed a European treaty only to see their parliaments or populations decline to ratify it'. ${ }^{118}$

Hence, this author perceives national parliamentary ratification debates as being exclusively restricted to the national domain, and seems to largely exclude the possibility of any meaningful form of interaction between the parliaments. To what extent can this be said to be true for the parliamentary debates on the EP elections too?

A final answer to this question and the one concerning MPs' participation in transnational networks cannot be given solely on the basis of parliamentary records, but a number of preliminary conclusions can certainly be drawn. First of all, it should be noted that several MPs, or at least those who were favourably disposed towards the elections, did feel situational pressure and wanted to prevent the disgrace of being at the end of the ratification peloton. ${ }^{119} \mathrm{~A}$ Belgian MP typically expressed his relief about the postponement of discussion in other member states' parliaments; now Belgium would probably not be the last member state to ratify. And he was not the only MP who cared; several colleagues gave expression to the need to keep up a good reputation abroad and to ensure a speedy ratification. ${ }^{120}$

116. E. O'CONNOR, op.cit., p.59. For examples of transnational network influence on other parts of European integration history, see, for instance: W. KAISER, Bringing history back in to the study of transnational networks in European integration, in: Journal of Public Policy, 2(2009), pp. 223-239, here pp.227-232.

117. V. HERMAN, op.cit., pp.16 and 20; G. BRUNN, op.cit., pp.52-53 and 56.

118. L. VAN MIDDELAAR, op.cit., p.89.

119. See, for instance: M. COTTA, op.cit., p.163; M.A. WING, op.cit., pp.179-180; J. LODGE, Germany: Modell Deutschland, op.cit., p.77; E. MOXON-BROWNE, op.cit., p.140.

120. See, for instance: Proceedings of the Belgian Chamber of Representatives, 10.07.1978, 25.07.1978 and 03.11.1978. 
Naturally, a precondition for such arguments to have any effect at all was a positive attitude towards European integration. In the United Kingdom, there were also representatives who feared the British name would be damaged if the target date were not met, but this did not make any impression on anti-market politicians. ${ }^{121}$ MPs arguing against the elections were simply more concerned about the consequences of a positive decision than about the country's reputation. They felt that the drift of the argument dominating in the majority of member states confirmed their fears. In France, the elections' fiercest opponent, Debré, pointed to far-reaching tendencies of supranationalism or even federalism that were present in Germany, Italy and the Benelux-countries, to underscore what the elections might mean for the independence of France. ${ }^{122}$ In the British House of Commons, the ideas of often unspecified 'continental' politicians were also pointed to in order to demonstrate that the elections were actually meant to stimulate further integration. 'Some of us talk to colleagues in Germany, the Netherlands and elsewhere who say openly that their objective is federalism', said one Labour MP, '[t]hey would laugh to scorn any suggestion that direct elections are not to do with federalism'.${ }^{123}$ Besides, didn't the Tindemans report predict that the "consequence of the Parliament's new authority will be an increase in its powers'? ${ }^{124}$ Although many considered the report as no more than a cautious attempt to design a European Union, it was much too radical for those who preferred a purely intergovernmental community. No wonder it was an important point of reference for parliamentarians who opposed the elections to illustrate what they did not want. ${ }^{125}$

Judging by the statements made, national parliaments shared a number of common points of reference, such as the Tindemans report, and could also give a rough sketch of the state of affairs in other national parliaments. When references to the legislative procedures in specific other member states were made, they were mostly related to the United Kingdom and France. In the Dutch parliament, several MPs expressed concern and irritation about the course of events in the national parliaments of these two states. ${ }^{126}$ A number of representatives also posed questions about the Danish reservations to the Act. ${ }^{127}$ In Ireland, feelings of rivalry tempted some MPs to compare the debate in their own parliament with the protracted discussions in their neighbouring country:

121. See, for instance: Proceedings of the British House of Commons, 25.03.1977, 20.04.1977, 06.07.1977 and 07.07.1977.

122. Proceedings of the French House of Representatives, 14.06.1977.

123. Proceedings of the British House of Commons, 30.03.1976 and 25.04.1977.

124. European Union. Report by Mr Leo Tindemans to the European Council, p.29. See: http:// aei.pitt.edu/942/1/political_tindemans_report.pdf (accessed: 23.02.2018).

125. See, for instance: Proceedings of the British House of Commons, 29.03.1976, 30.03.1976, 12.07.1976, 25.04.1977 and 06.07.1977; Proceedings of the Danish Parliament, 11.12.1975, 20.10.1977 and 29.11.1977.

126. Proceedings of the Dutch House of Representatives' Committee for Foreign Affairs, 21.03.1977; Proceedings of the Dutch House of Representatives, 22.06.1977.

127. Proceedings of the Dutch House of Representatives' Committee for Foreign Affairs, 21.03.1977. 
'[w]e have been very successful in preparing this Bill, but the British are dragging their heels. If it does not suit England they just do not bother'. ${ }^{128}$

On their part, British MPs took a special interest in France. For some of them, the French Gaullist Party obviously served as an example. 'I am an unashamed Gaullist', declared one Conservative member of parliament. ${ }^{129}$ British MPs also found a very concrete source of inspiration in the French clause on the European Parliament's future powers. Although a different formulation was chosen, words of similar meaning were included in an additional article to the British bill. The initiators in parliament said they had taken the French law as an example. ${ }^{130}$

Unless there was a specific reason, MPs did, however, not generally show much interest in the details of the other parliaments' debates. Irish MPs took notice of the British election system, because of the consequences this might have for the Catholic minority in Northern Ireland, which they felt connected with. ${ }^{131}$ In the Netherlands, the Social Democrats collected information for an overview with some basic information on the choice for either the territoriality or nationality principle and a summary of the days of voting and vote counting in each member state, which were both topics that were under debate in the Dutch parliament. ${ }^{132}$ But these were exceptions; on the whole, references to the particulars of each state's implementation laws, let alone to the parliamentary debates behind them, are rarely found in the parliamentary records. Insofar as cross-border references were made, focus revolved mostly around the Brussels centre with no more than occasional side-views to debates in other member states. Even though there may have been individual MPs with extensive transnational contacts, on the face of it, parliamentary ratification debates did not generally bear more than just a few clearly distinguishable transnational imprints. Cross-border influences were not completely absent, but were never all-important for the eventual outcome in national parliament.

\section{Conclusions}

According to the Liberal German MP, and later European Commissioner, Martin Bangemann, the future Europe would be a Europe of minorities:

'No nation has a majority in this community. No language has a majority in this community. Neither party will have an absolute majority in this community'. ${ }^{133}$

128. Proceedings of the Irish House of Representatives, 27.10.1977.

129. Proceedings of the British House of Commons, 24.11.1977.

130. Proceedings of the British House of Commons, 07.07.1977.

131. Proceedings of the Irish House of Representatives, 27.10.1977; Proceedings of the Irish Senate, 07.12.1977.

132. Written comments on the Dutch European Elections Bill (15 044, no.5).

133. Proceedings of the German Bundestag, 26.05.1977. 
This article has demonstrated that this diversity existed also with respect to the question what European democracy should look like. Expectations and ideas that existed about the location of European democracy, the nature of the European Parliament and its relation with national parliaments differed considerably between as well as within national parliaments. With respect to these questions, the MPs general attitude towards European integration usually played a decisive role.

Two camps can be constructed from the national debates: long-term parliamentarization of the European Community was welcomed in the Benelux countries, the Federal Republic of Germany and Italy, whereas the parliaments of the United Kingdom, France, Denmark and - to a lesser extent - Ireland tended to emphasize their national sovereignty. Broadly speaking, there was a dividing line between the EC's founding nations and the member states that had entered the Community in 1973. There were clear parliamentary majorities in favour of a strong and directly elected European Parliament in the Federal Republic of Germany, Italy, the Netherlands, Belgium and Luxembourg. Among the old member states, France was the exception. In the United Kingdom and Denmark, the direct elections proposal encountered with considerably more resistance than in the older member states, and for British and Danish MPs it was beyond doubt that national parliament should continue to be the primary location for democracy to take place. In Ireland, the third new member state, the elections were welcomed, but as the Irish MPs perspective on the MEPs' main duty in European Parliament demonstrated, European sympathies were not as deeply rooted as they were in most of the older member states.

Generally speaking, opposition against direct elections and a stronger European Parliament was strongest at the political left. Except for Italy, Communist Parties in all member states were very critical, but due to their minority position their opposition did not have much impact. Internal opposition within the ranks of British Labour and the Danish Social Democratic Party appeared harder to ignore, and caused the two countries' governments considerable trouble. And even though it did not really effect the ratification debates in the Netherlands, it should perhaps be mentioned that the Dutch Social Democrats were confronted with a critical anti-EC wing too in these years. ${ }^{134}$

Each European society had to contemplate about the question who should be represented at a European level. Obviously, the question whom MEPs primarily speak for was also influenced by the MP's view on the integration process, but here, national customs and domestic political struggle came into play as well. In some member states, there was a tradition of regional representation, and in Belgium, the question of the language groups was an important factor. Sometimes views that followed from national parliamentary traditions or power struggles could easily be reconciled with European convictions, in other instances, they pointed in different directions. Especially the Belgian debate made an ambivalent impression.

134. See: H. REIDING, 1973-1986: De teleurstellende Europese werkelijkheid, in: A.G. HARRYVAN, J. VAN DER HARST (eds), Verloren consensus. Europa in het Nederlandse parlementair-politieke debat, 1945-2013, Boom, Amsterdam, 2013, pp.103-142, here p.108. 
Finally, when it came to the nature of the voter and the link with the people, arguments got even more confusing and inconsistent. This was particularly true for federally inspired MPs: there were legitimate democratic concerns (e.g. the unequal representation of bigger and smaller member states' population), and the gap which still existed between European ideals and European reality made it difficult to defend consistently what the European ideals required. Hence, as it turned out, it did not go without saying that a citizen who was working in another member state would also have the right to vote for European Parliament, and giving such persons the right to stand for election in the country of residence was never really an option at all.

What this article has also demonstrated is that, in these years, national parliaments could only to a very limited extent be seen as truly European actors. Although the type of arguments that were exchanged in the debates were often comparable, and there were certain common points of reference, only a general awareness existed of what happened in the other national parliaments. It is perfectly possible that some individual MPs (for instance those with a dual mandate) were part of a pan-European network, but as far as the configuration of the parliamentary debates was concerned, the national contexts played the dominant role.

Nonetheless, it could be worthwhile for future historical research to further investigate national MPs' participation in transnational networks and their influence on debates concerning direct European elections or other European issues. It would also be interesting to know whether any convergence of ideas about European democracy can be traced over time. In light of the various, often even contradictory, points of view that member states' national politicians took with respect to a number of fundamental questions concerning parliamentary representation in Europe in the 1970 s, it is hardly surprising that it has proven problematic to realize a European form of democracy that satisfies all. Even today, the debate continues without any end in the foreseeable future. 